\title{
IRREVOCABILITY OF PERFORMANCE RENDERED FOR MUTUALLY ILLEGAL OR IMMORAL PURPOSE IN ROMAN LAW, GERMAN LAW, AND ENGLISH LAW
}

\begin{abstract}
This paper deals with the very difficult problem of recovery of a performance rendered for illegal or immoral purpose where both parties, the giver and the recipient, violate law or offend good morals. In such a situation their contract is invalid and the parties cannot claim the counterperformance or damages for non-performance; however, if the performance has already been made, the question arises what to do with it, in particular whether the subject of the performance should be given back, or can be retained by the recipient. The crux of the problem is that where both parties are equally in the wrong, neither deserves legal protection or privileged legal position.

This paper presents how the problem is solved in three very important legal systems that have developed rules which have served as a model for regulations or case law in many countries. The solution proposed by Roman law and adopted in German and English law is that there is no recovery - the giver is not entitled to claim his performance back. At a very general level this solution is justified by the Latin maxim in pari delicto pari potiorem esse possessorem (Roman law), in pari turpitudine melior est causa possidentis (German law) or in pari delicto potior est conditio defendentis (common law). In fact, only Roman law resolved that problem in the very simple way suggested by the maxim, while in both German and English law the solution and policy behind it are much more complicated. Apart from the main course of the analysis, the paper contains: a brief description of the category of performance rendered for illegal or immoral purpose, an analysis of the bar to recovery of the performance, exceptions to the bar, justification of the adopted solution and disputes in the law doctrine and in case law concerning that issue.
\end{abstract}

Keywords

unjustified enrichment - performance for illegal or immoral purpose - in pari delicto melior est conditio possidentis (defendentis)

* Dr. habil., Faculty of Roman Law, Nicolaus Copernicus University, solicitor. 


\section{INTRODUCTION}

Modern civil law knows the category of performance made for an illegal or immoral purpose. This concept has roots in Roman law, particularly in a special claim designed to recover such a performance condictio ob turpem causam. This issue belongs to the field of unjustified enrichment, which, besides contract and delict (tort), is the main source of obligations. The performance made for an illegal or immoral purpose and the rules governing its restitution impose one of the most difficult problems in civil law. The most questionable aspect is the case where both parties - the giver and the recipient - are tainted by evil or violate the law, especially a statutory prohibition. In that case neither of them deserves protection against the other ${ }^{1}$. The law should not protect a person who intentionally and seriously violates statutory prohibitions or moral standards. However, something must be done with the performance already made and the law should provide us with proper solution to the problem. There is no solution which is free from disputes, controversy, and drawbacks, but every legal system must decide whether to enable the giver to claim the restitution of his performance. General rules on undue performance are insufficient here because they do not take into account the distinctive feature of the performance - its illegal or evil purpose.

In this paper I do synthetic research into three legal systems which contain the most representative solutions - Roman, German and English law. In fact, all these systems operate with a solution which, at a very general level, can be described as the same and which is framed in the maxim "in pari delicto (turpitudine) melior est conditio (causa) possidentis (in Roman and German law) or defendentis (in common law)". The crux of this solution is the bar to the recovery of the performance where the parties are equally tainted. It fact, this similarity exist only at a very general level, because there are many important divergences in details.

1 As R. Zimmermann writes "under those circumstances, it is preferable to leave things as they are, rather than to assist one villain in his claim against the other" (R. Zimmermann, The Law of Obligations. Roman Foundations of the Civilian Tradition, Cape Town-WettonJohannesburg: Juta 1990, p. 846), similarly H. Honsell, Die Rückabwicklung sittenwidriger oder verbotener Geschäfte, München: C.H. Beck 1974, p. 90. 
I deliberately refrain from presenting the Polish solution contained in the Article 412 of Polish Civil Code because it differs entirely from the ones quoted above and does not rely on the common maxim in pari delicto. Therefore there is no place to make reasonable comparison apart from the general conclusion that Polish law operates with the sanction of forfeiture of the performance.

\section{ROMAN LAW}

In Roman classical law legal transactions which violated law or offended good morals (boni mores) were invalid according to the principle that neque contra leges neque contra bonos mores pacisci possumus ${ }^{2}$. Good morals, besides the law itself, constituted a basic criterion of the assessment of legal transactions ${ }^{3}$. The principle referred to both contracts recognized by law and other agreements that were not regarded as contracts 4 .

The invalidity of a legal transaction does not mean that the transaction never took place, because something has to be done with the performance already delivered, as especially the question arises whether and on what conditions it has to be given back to the giver. Here we tackle the field named in modern law "unjustified enrichment". In Roman law there was no universal principle that every benefit which was gained at the expense of another person without a legal ground must be restored to the impoverished person. Roman jurists recognized the restitution

2 See: PS 1.1.4, cf. D.28.7.14 (Marc. 4 inst.), D.30.112.3 (Marc. 6 inst.), PS 3.4b.2, C.2.3.6, C.2.3.30.3.

3 P. Lotmar, Der Unmoralische Vertrag insbesondere nach gemeinem Recht, Leipzig: Duncker \& Humbolt 1896, p. 43 et seq.; M. Kaser, Rechtswidrigkeit und Sittenwidrigkeit im klassischen römischen Recht, ZSS 1940, no. 60, p. 120 et seq.; T. Mayer-Maly, Contra bonos mores, [in:] M. Kaser; H.-P. Benohr (eds), Iuris Professio. Festgabe für Max Kaser zum 80. Geburtstag, Wien-Köln-Graz: H. Bohlau 1986, p. 154; M. Kuryłowicz, Prawo i obyczaje w starożytnym Rzymie [Law and Morals in Ancient Rome], Lublin: Lubelskie Wydawnictwo Prawnicze 1994, p. 137 et seq.

4 In this context it is important to remember that there was no freedom of contract in Roman law, but only certain agreements expressly recognized as contracts were protected by law and entitled their parties to initiate a civil trial to enforce the promise. It can be described as system of fixed contractual types - only where there was an action to enforce the promise (in fact procedural formula that fitted the circumstances of the case) was the agreement a contract. 
obligation only in certain situations where they applied actions called condictiones. There is no place here to describe all condictiones known in Roman law, but it suffices to say that the restitution was possible by means of condictio indebiti 5 , condictio ob rem ${ }^{6}$ (later named condictio causa data causa non secuta), condictio ob turpem causam ${ }^{7}$, condictio sine causa ${ }^{8}$ and condictio ex causa furtiva9.

In case of performance made for an illegal or immoral purpose, condictio ob turpem causam could be applied. The most popular view among scholars regards this condictio only as a subcategory of condictio ob rem ${ }^{10}$. The latter claim had general character and could be used to demand return of performance made for a purpose that was not achieved ${ }^{11}$.

The great classical jurist Paul indicated fundamental distinctions between various types of purpose of performance:

D.12.5.1pr.-2 (Paul. 10 ad Sab.)

Omne quod datur aut ob rem datur aut ob causam, et ob rem aut turpem aut honestam: turpem autem, aut ut dantis sit turpitudo, non accipientis, aut ut accipientis dumtaxat, non etiam dantis, aut utriusque. 1. ob rem igitur honestam datum ita repeti potest, si res, propter quam datum est, secuta non est. 2. quod si turpis causa accipientis fuerit, etiamsi res secuta sit, repeti potest.

\footnotetext{
5 D.12.6, C.4.5.

6 D.12.4, C.4.6.

7 D.12.5, C.4.7.

8 D.12.7, C.4.9.

9 D.13.1, C.4.8.
}

10 I. von Koschembahr-Łyskowski, Die condictio als Bereicherungsklage im klassischen römischen Recht, Weimar: Hermann Bohlau 1903, vol. 1, p. 207 et seq.; F. Schwarz, Die Grundlage der condictio im klassischen römischen Recht, Münster-Köln: Böhlau 1952, p. 169 et seq.; Honsell, supra note 1, p. 65, 80; B. Kupisch, Arricchimento nel diritto romano, medievale e moderno, [in:] Digesto delle Discipline privatistiche. Sezione civile, vol. 1, Torino: UTET 1987, p. 429 et seq.; idem, Ungerechtfertigte Bereicherung. Geschichtliche Entwicklungen, Heidelberg: V. Decker \& Müller 1987, p. 14; Zimmermann, supra note 1, p. 845; J.D. Harke, Das klassische römische Kondiktionensystem, IURA 2003, p. 54; idem, Römisches Recht: von der klassischen Zeit bis zu den modernen Kodifikationen, München: C.H. Beck 2008, p. 193 et seq.; P. Księżak, Świadczenie niegodziwe [Immoral Performance], Warszawa: C.H. Beck 2007, p. 10; A. Jurewicz, [in:] A. Jurewicz, R. Sajkowski, B. Sitek, J. Szczerbowski, A. Świętoń, Rzymskie prawo publiczne. Wybrane zagadnienia [Roman Public Law. Selected Issues], Olsztyn: Wydawnictwo Uniwersytetu Warmińsko-Mazurskiego w Olsztynie 2011, p. 298.

11 On this claim see my Świadczenie w zamierzonym celu, który nie zostat osiagniety. Studium $z$ prawa rzymskiego [Performance Rendered for an Intended Purpose that Has Not Been Achieved. Study in Roman Law], Torun: TNOiK 2012, with literature mentioned there. 
"Everything given is given either because of a purpose envisaged (ob rem) or on assumed basis (ob causam), and in respect of things given ob rem some are evil and some honourable". In Paul's time both terms $o b$ rem and $o b$ causam had similar meanings and both referred to the purpose of the performance. Paul made two further divisions - the first between an evil and an honourable purpose and the second concerning the evil purpose. What was given for an honourable purpose could not be reclaimed unless the purpose envisaged failed to materialize. In other words, as a rule datio ob rem honestam could not be reclaimed where the honourable purpose was achieved ${ }^{12}$. The problem of recovery of datio ob rem turpem was more complex, as was illustrated in the last division: "the giver might be in the wrong and not the recipient, or the recipient not the giver or both might be".

This fragment proves that three types of turpitudinous purpose of performance were discerned: turpitudo solius accipientis, turpitudo solius dantis, and turpitudo utriusque partis. Every type had its own specific effects. However, in all those cases the recovery of performance was independent from achievement of the evil purpose of the performance. This was the fundamental difference between datio ob rem and datio ob turpem causam.

Turpitude only on the recipient's side referred to two groups of cases, first: where the giver paid money to induce the recipient not to commit a crime or delict, e.g. not to commit sacrilege, not to steal, not to kill a man ${ }^{13}$, nor not to commit iniuria ${ }^{14}$; second: where the recipient demanded extra payment for an action that he was already obliged to undertake, for instance the giver paid to make him return something deposited with him, e.g. a document ${ }^{15}$ or a thing given for use ${ }^{16}$. In both groups the recipient was obliged by law or contract to perform the action for which he demanded extra money, and that is why his demand infringed morality.

\footnotetext{
12 This fundamental rule is confirmed by sources contained in the Digests' title De condictione causa data causa non secuta (D.12.4).

13 D.12.5.2pr.-1 (Ulp. 26 ad ed.).

14 D.12.5.4.2 (Ulp. 26 ad ed.).

15 D.12.5.2pr.-1 (Ulp. 26 ad ed.).

16 D.12.5.9pr. (Paul. 5 ad Plaut.), see also D.12.5.9.1 (Paul. 5 ad Plaut.).
} 
In all the abovementioned cases the giver was entitled to claim his payment back regardless of the achievement of its purpose (quotiens autem solius accipientis turpitudo versatur, Celsus ait repeti posse) ${ }^{17}$, it was enough that the recipient had acted for immoral purpose and the giver did not share that purpose.

Only one example of turpitudo solius dantis is mentioned in the surviving sources - payment given to a prostitute for her service ${ }^{18}$. On one hand, Ulpian decided here that the prostitute did not act for an immoral purpose, so she is entitled to retain the money ${ }^{19}$. On the other hand, only the giver's purpose was immoral and that is why he could not demand restitution.

The most important and difficult case is turpitudo utriusque partis, the case where both the giver and the recipient made a transaction for an immoral purpose. The majority of the surviving sources deal with such a situation. Basic examples are: performance given for sexual malpractice between a man and an unmarried woman other than one in slavery or concubinage or between two men (stuprum) or where one caught in adultery (adulterium) buys his way out ${ }^{20}$, bribery given to a judge for a favourable judgment ${ }^{21}$ or to pervert a judgment ${ }^{22}$, payment for not denouncing a theft committed by the giver ${ }^{23}$.

It should be stressed that only the most serious infringements of good morals justified the application of the special rules of restitution of performance. All the examples mentioned above are grave offences against morality. The fact itself that an agreement was contrary to good

\footnotetext{
17 D.12.5.4.2 (Ulp. 26 ad ed.).

18 D.12.5.4.3 (Ulp. 26 ad ed.). note 11, p. 241 et seq.

20 D.12.5.4pr.-1 (Ulp. 26 ad ed.).

21 D.12.5.2.2 (Ulp. 26 ad ed.).

22 D.12.5.3 (Paul. 10 ad Sab.).

23 D.12.5.5 (Iul. 3 ad Urs. Fer.), D.12.5.4.4 (Ulp. 26 ad ed.).
}

19 This solution in explained in many divergent ways see: G. Grosso, Il prezzo del meretricio, SDHI 1943, no. 9, p. 289 et seq.; G. Sciascia, A paga à meretriz no direito romano, [in:] G. Sciascia, Varietà giuridiche, Scritti brasiliani di diritto romano e moderno, Milano: A. Giuffrè 1956, p. 19 et seq.; F. Sturm, Quod meretrici datur repeti non potest, [in:] M. Kaser; H.-P. Benöhr (eds), Iuris Professio. Festgabe für Max Kaser zum 80. Geburtstag, Wien-Köln-Graz: H. Böhlau 1986, p. 281 et seq.; W. Dajczak, A. Sokala, Ulp. D.12.5.4.3, Ein Beitrag zur Klärung der nova ratio, TR 1990, no. 58, p. 129 et seq.; A. Sokala, Meretrix i jej pozycja w prawie rzymskim [Meretrix and Her Position in Roman Law], Torun: Wydawnictwo UMK 1998, p. 89; Sobczyk, supra 
morals was insufficient where the infringement was not grave enough. It is interesting to observe that majority of applications of the condictio ob turpem causam referred to offences against good morals, not against the law. Roman jurists distinguished between boni mores and the law itself. Only in the law of Justinian they combined illegal with immoral purpose and create action called condictio ob turpem vel iniustam causam, however the turpis causa remained dominant.

The solution of mutual immorality was very simple:

D.12.5.3 (Paul. 10 ad Sab.):

Ubi autem et dantis et accipientis turpitudo versatur, non posse repeti dicimus.

When the evil tainted both giver and recipient the recovery was excluded regardless of whether the purpose of the performance was achieved or not.

The question is what the justification of this solution was. Roman jurists gave only one answer to this question:

D.12.7.5pr. (Papin. 11 quest.):

Avunculo nuptura pecuniam in dotem dedit neque nupsit: an eandem repetere possit quaesitum est. dixi, cum ob turpem causam dantis est accipientis pecunia numeretur, cessare condictionem et in delicto pari potiorem esse possessorem: quam rationem fortassis aliquem secutum respondere non habituram mulierem condictionem: sed recte defendi non turpem causam in proposito quam nullam fuisse, cum pecunia quae daretur in dotem converti nequiret: non enim stupri, sed matrimonii gratiam datum est.

Papinian referred here to payment made as a dowry by a woman who was about to be married to her maternal uncle, but did not marry him. The question arose as to whether she could bring an action for the recovery of the money, because usually property given as a dowry on account of a future marriage could be claimed back where the marriage did not follow ${ }^{24}$. In this case the marriage was to be concluded with close relative - the brother of the woman's mother. Sexual intercourse between close relatives was regarded as incestum, one of the crimes known

24 About the recovery of dotal property in a case when the planned marriage did not take place see Sobczyk, supra note 11, p. 163 et seq. with further literature mentioned there. 
in Roman law $^{25}$ and for this reason the purpose of the performance - a dowry on account of incestuous marriage - contravened good morals, so condictio ob turpem causam could be taken into consideration.

In that respect Papinian took into consideration two solutions. First of all, he recalled the well established view that where money was paid on immoral basis (causa) which affected the giver and the recipient, condictio would not lie, and "where both parties are equally in the wrong, the possessor is the stronger". Here, both the woman and her uncle were affected by the immoral causa and were equally in the wrong, and thus it seemed apparently that she was not entitled to restitution of the dotal property, because the uncle possessed the property and as a possessor he had better position. Second of all, Papinian himself, however, proposed the opposite solution, namely, he indicated that there was no basis at all and no evil basis, since it was not possible for the money which had been given ever to become a dowry, the point being that it was given not for improper sexual relations, but for the marriage. This way the jurist came to conclusion that the performance lacked any legal justification at all, not that its purpose was immoral26.

Particularly important in the jurist's reasoning was the rule in delicto pari potiorem esse possessorem, the fact itself that the recipient already possessed the object of the performance places him in a better position in spite of his being equally immoral as the giver. The objective state of possession was decisive and there was no need to search for any other justifications.

The same principle was recalled by Paul in reference to a stipulation made on an evil basis (ob turpem causam): autem si et dantis et accipientis turpis causa sit, possessorem potiorem esse et ideo repetitionem cessare ${ }^{27}$ (where both parties, the giver and the recipient were immoral, the possessor was stronger and hence an action for recovery did not lie).

\footnotetext{
25 See J. Misztal-Konecka, Incestum $w$ prawie rzymskim [Incestum in Roman Law], Lublin: Wydawnictwo KUL 2006, p. 46 et seq.

26 Cf. ibidem, p. 188, while R. Mayer-Spache overlooks the fact that in this case a valid marriage could not be concluded at all (The Recovery of Benefits Conferred under Illegal or Immoral Transactions. A Historical and Comparative Study with Particular Emphasis on the Law of Unjustified Enrichment, Aberdeen: University of Aberdeen 2002, p. 36 et seq.).

27 D.12.5.8 (Paul. 3 quest.).
} 
The principle in pari delicto is mentioned in several other sources 28 , and was the emanation of the general rule in pari causa possessor potior haberi debet 29 "in an equally balanced case, the possessor must be regarded as the stronger".

This general rule gave the possessor a favourable position in litigations, especially in rei vindicatio suits where the claimant had to prove his title to the thing in question, while the possessor could rely only on the objective fact of his possession. In other cases pertaining to property rights where the claimant did not manage to prove that he had a better right than the possessor, the judgment had to be given in favour of the possessor ${ }^{30}$. In my opinion the biggest advantage of the principle, apart from its simplicity, is that, because of the lack of justification for legal protection of either of the parties, it allowed the status quo to remain, preventing any changes which could not be axiologically approved ${ }^{31}$. This principle cannot be regarded as a penal sanction affecting the giver who offended the moral standards 32 . However, to some extent I share the view that the principle was very formal and not fully convincing 33 . Nevertheless, Roman law did not manage to elaborate a better solution or more convincing justification for this principle. In fact Roman law gave a very short and simple answer to the problem of turpitudo utriusqe partis, but this brevity and simplicity is a manifestation of the way of reasoning of jurists, who tried to find the simplest and the most convenient solution, instead of highly elaborated and complicated theories typical of the jurists of today. The application of in pari delicto rule was not confined to cases where an evil purpose was not achieved ${ }^{34}$. This rule remained important where an evil purpose had been realized. Where the purpose of the performance was honourable there was no room for the in pari delicto rule.

\footnotetext{
28 D.3.6.5.pr.-1 (Ulp. 10 ad ed.), C.4.7.2.

29 D.50.17.128pr. (Paul. 19 ad ed.).

30 See examples given in D.6.2.9.4 (Ulp.16 ad ed.), D.43.33.1.1 (Iul. 49 dig.), D.20.1.10 (Ulp. 73 ad ed.), D.50.17.154 (Ulp. 70 ad ed.). Cf. Honsell, supra note 1, p. 89; Mayer-Spasche, supra note 26, p. 28 et seq.

31 Honsell, supra note 1, p. 90, Księżak, supra note 10, p. 17; idem, Bezpodstawne wzbogacenie. Art. 405-414 KC. Komentarz [Unjustified Enrichment. Art. 405-414 of Polish Civil Code. Commentary], Warszawa: C.H. Beck 2006, p. 12.

32 Mayer-Spasche, supra note 26, p. 34; Księżak, supra note 10, p. 17.

33 Schwarz, supra note 10, p. 188.

34 Mayer-Spasche, supra note 26, p. 13.
} 


\section{GERMAN LAW}

German unjustified enrichment law makes a fundamental distinction between two groups of claims: condictions due to undue enrichment (Leistungskondiktionen) and condictions due to other transfers of property without legal ground - so called "non-performance condictions" (Nichtleistungskondiktionen), known also as an enrichment "by other means" 35 . Performance (Leistung) is understood here as every conscious, intentional increase in another's property ${ }^{36}$. The German concept of unjustified enrichment is a product of the Pandectist School of the nineteenth century strongly influenced by the sources of Roman law and various condictiones worked out by Roman lawyers ${ }^{37}$. German law has taken over from Roman law condictio indebiti38, condictio sine causa ${ }^{39}$, condictio ob causam finitam ${ }^{40}$, condictio causa data causa non secuta ${ }^{41}$. The last important claim created by Roman classical jurists - condictio ob turpem causam is known in German law too. The non-performance condictions or "enrichment by other means" refer to infringement (Eingriff), expenditure (Verwendung), recourse (Rückgriff) ${ }^{42}$.

The problem of recovery of performance made for an immoral purpose is regulated in $\S 817$ of BGB: if the purpose of a performance was determined in such a way that the recipient, in accepting it, was

\footnotetext{
35 On this distinction see G. Dannemann, German Law of Unjustified Enrichment and Restitution. A Comparative Introduction, Oxford: Oxford University Press 2009, p. 21 et seq. 36 See: BGHZ 58,184,188; D. Medicus, Bürgerliches Recht: eine nach Anspruchsgrundlagen geordnete Darstellung zur Examensvorbereitung, Köln-Berlin-München: Heymanns 2004, p. 465; H. Brox, W.D. Walker, Besonderes Schuldrecht, München: C.H. Beck 2006, p. 470.

37 About achievements of Pandectist School in the field of unjust enrichment see F.L. Schäfer, [in:] J. Rückert; Ch. Birr; M. Schmoeckel (eds), Historisch-kritischer Kommentar zum BGB, Band III, Schuldrecht: Besonderer Teil, Teilband II, Tübingen: Mohr Siebeck 2013, p. 2601 et seq. $38 \S 812$ 1(1) of German Civil Code (BGB): who obtains something as a result of the performance of another person (condictio indebiti) or otherwise (condictio sine causa) at his expense without legal grounds for doing so is under a duty to make restitution to him.

39 Ibidem.

$40 \S 8121(2)$ : This duty also exists if the legal grounds later lapse (condictio ob causam finitam) or if the result intended to be achieved by those efforts in accordance with the contents of the legal transaction does not occur (condictio causa data causa non secuta).

41 Ibidem.

42 B.S. Markesinis, W. Lorenz, G. Dannemann, The Law of Contracts and Restitution: A Comparative Introduction, [in:] The German Law of Obligations, vol. I, Oxford: Clarendon Press 1997, p. 714 et seq.
} 
violating a statutory prohibition or good morals, then the recipient is obliged to make restitution. A claim for return is excluded if the person who rendered performance was also blamed for such a violation, unless the performance consisted in entering into an obligation; restitution may not be demanded of any performance rendered in fulfilment of such an obligation ${ }^{43}$.

The first sentence has its roots in the Roman condictio ob turpem causam. However, the sentence refers only to a performance for an illegal or immoral purpose only on the recipient's side which resembles the Roman law concept of turpitudo solius accipientis. The solution is identical as it was in the Roman times - the giver can claim restitution. The scope of application of the condictio ob turpem causam in German law is very narrow ${ }^{44}$. This claim is described even as "fast bedeutungslose" (almost meaningless) 45 .

The second sentence deals with the mutual illegality and immorality which is equivalent to Roman turpitudo utriusque partis. As a rule, a claim for return is excluded if the person who rendered performance was also blamed for such a violation. This bar to recovery is often regarded as a German expression of the maxim in pari turpitudine melior est causa possidentis. It has been said also that the proper purpose of the provision derives from the maxim nemo turpitudinem suam allegans 46 .

In fact, the issue is much more complex than the application of those simple principles and, in spite of its roots in Roman law, the German solution takes patterns from Roman law only to a very limited extent. "It is noteworthy that the courts' judgments devote comparatively little space to the in pari turpitudine rule itself. They rush to their conclusion

\footnotetext{
43 War der Zweck einer Leistung in der Art bestimmt, dass der Empfänger durch die Annahme gegen ein gesetzliches Verbot oder gegen die guten Sitten verstoßen hat, so ist der Empfänger zur Herausgabe verpflichtet. Die Rückforderung ist ausgeschlossen, wenn dem Leistenden gleichfalls ein solcher Verstoß zur Last fällt, es sei denn, dass die Leistung in der Eingehung einer Verbindlichkeit bestand; das zur Erfüllung einer solchen Verbindlichkeit Geleistete kann nicht zurückgefordert werden.

44 Medicus, supra note 36, p. 491; Brox, Walker, supra note 36, p. 468; O. Mühl, W. Hadding, [in:] Soergel Kommentar zum Bürgerlichen Gesetzbuch, Band 5/1, Schuldrecht IV/1, Stuttgart: Verlag W. Kohlhamme 2007, p. 1196; M. Lieb, [in:] Münchener Kommentar zum Bürgerlichen Gesetzbuch, Band 5, Schuldercht. Besonderer Teil III, München: C.H. Beck 2007, p. 1393 et seq.

45 D. Medicus, Schuldrecht II. Besonderer Teil, München: C.H. Beck 2006, p. 248.

46 Medicus, supra note 36, p. 492 et seq.; idem, supra note 45, p. 249.
} 
as if they were a little embarrassed to deny a claim on such a tedious ground" 47 .

First of all, it should be stressed that the German provision is surrounded by many disputes and uncertainties. It is one of the most disputable provisions in the German Civil Code ${ }^{48}$. It has been called "one of the most dreaded perils in the sea of legal doctrine" 49 . In D. Medicus' view the provision in question is unsuccessful in its content, questionable in its purpose, and doubtful in its effects in terms of policy of law ${ }^{50}$. Almost every particular problem in the interpretation of this provision or its application gives rise to many disputes and controversies. Even the need for this provision, especially the first sentence, is questionable ${ }^{51}$.

The field of application of the second sentence of $\S 817$ (§ 817 (2)) is much wider than suggested by its content. As a rule, a contract that violates law or good morals is void ( $\S \S 134,138$ ), so the performance is undue and can be claimed back on the basis of $\S 812$ I (1). It concerns a situation where here both parties are responsible for the illegality, as onesided illegality will frequently not render a contract void ${ }^{52}$. This general rule on undue performance is modified in $\S 817$. According to the content of $\S 817$ (2) it refers to the condictio ob turpem causam which is regulated in the first sentence. However, it is applied also in cases of condictio indebiti § 812 I (1) and to the performances made under the void contract (§§ 134 and 138)53. In this way it is impossible to evade the negative

\footnotetext{
47 Dannemann, supra note 35, p. 318.

48 Księżak, supra note 10, p. 32.

49 Zimmermann, supra note 1, p. 864, cf. Medicus, supra note 45, p. 246.

50 Medicus, supra note 45, p. 248.

51 See the doctrine's view in Lieb, supra note 44, p. 1392.

52 G. Dannemann, Illegality as a defence against unjust enrichment claims, [in:] D. Johnston, R. Zimmermann (eds), Unjust Enrichment. Key Issues in Comparative Perspective, Cambridge: Cambridge University Press 2002, p. 310.

53 The discussion about the field of application of this provision is presented in: Medicus, supra note 36, p. 492; idem, supra note 45, p. 248; Mühl, Hadding, supra note 44, p. 1201 et seq.; Lieb, supra note 44, p. 1394 et seq.; Schäfer, supra note 37, p. 2618; Księżak, supra note 10, p. 32 et seq.
} 
consequences of $\S 817$ (2) by founding one's claim on $\S 812$ I (1) 54 . This provision does not apply in cases of non-performance condictions ${ }^{55}$.

It should be stressed that if provisions of $\S 817$ (2) were not applied outside the scope of condictio ob turpem causam, it would lose its significance 56 ; however, in its wider field of obligation it becomes important 57 .

According to the content of the $\S 817$ (2) it is applicable in cases of mutual illegality or mutual immorality, such as a situation where both parties offend either a statutory prohibition or good morals. In this respect, it is also applicable much more broadly, namely, in cases where only the giver acts against a statutory prohibition or good morals ${ }^{58}$. This wide application is justified by the view that in case of unilateral illegality or turpitude on the giver's side, the giver should not be in a better position than the innocent recipient ${ }^{59}$. This reasoning is an a fortiori argument ${ }^{60}$. In case of the illegality or immorality only on the recipient's side the solution is very simple - there must be recovery ${ }^{61}$.

There are several theories that have justified the German solution of irrecoverability of performance rendered for a mutually unlawful or immoral purpose. The oldest justification, and dominant several decades ago, is the theory of punishment ${ }^{62}$ (Straftheorie). Today the herschende Meinung says that the $\S 817$ (2) does not have penal character ${ }^{63}$ and the punishment itself cannot be regarded as the sole purpose of the provision, because the exclusion of the recovery is in favour of the recipient who can retain the payment in spite of being equally

\footnotetext{
54 Brox, Walker, supra note 36, p. 472.

55 Lieb, supra note 44, p. 1396; H. Gramm, [in:] Beck'sche Kurzkommentare, Band 7, Palandt, Bürgerliches Gesetzbuch, München: C.H. Beck 2004, p. 1201; Księżak, supra note 10, p. 35.

56 Medicus, supra note 45, p. 248; cf. Brox, Walker, supra note 36, p. 469; Lieb, supra note 44, p. 1395; Księżak, supra note 10, p. 33.

57 Brox, Walker, supra note 36, p. 470.

58 Medicus, supra note 45, p. 248; Mühl, Hadding, supra note 44, p. 1201; Lieb, supra note 44,

p. 1396; Gramm, supra note 55, p. 1202; Schäfer, supra note 37, p. 2618.

59 Medicus, supra note 45, p. 248.

60 Schäfer, supra note 37, p. 2618; Księżak, supra note 10, p. 35.

61 Brox, Walker, supra note 36, p. 471.

62 Medicus, supra note 45, p. 248.

63 Brox, Walker, supra note 36, p. 471; Mühl, Hadding, supra note 44, p. 1200; Lieb, supra note 44, p. 1394.
} 
at fault. Furthermore, it is stressed that civil law should not operate with penal sanction and should not encroach the field of penal law ${ }^{64}$.

The next justification refers to the compensation of mutual debts of the parties (Schuldkompensation), but it is rejected65. Another ratio legis sees in the provision an expression of the good faith doctrine (Treu und Glauben). The doctrine permits the non-application of the provision in certain cases in which invoking it can be seen as an abuse of right. However, reference to good faith does not explain or justify the German solution 6 .

Nowadays, the dominant view seeks the justification for the German solution in the theory of Rechtsschutzversagung, (the refusal of legal protection). The doctrine is very flexible, and thus it is applicable in many different situations and allows for making necessary distinctions ${ }^{67}$. There are various different particular motives which justify the doctrine. One of the justifications states that no one should be allowed to found his action on his own illegal or immoral conduct, therefore such claims will not be heard in the court ${ }^{68}$. Another: a person who acts outside the law and good morals places himself outside the sphere of the legal order and legal protection ${ }^{69}$. Also, it is justified by the claim that people should not be rewarded for their own illicit behaviour ${ }^{70}$. Even the maxim nemo venire contra factum proprium and English doctrine of clean hands are invoked in the doctrine ${ }^{71}$.

Some of other views require references:

The claim must be disallowed in order to deter illegal or immoral conduct. Owing to the fact that in a mutually illegal or immoral contract neither of the parties has contractual rights or can claim restitution of his own performance, the provision discourages people from engaging in such transactions ${ }^{72}$. The risk taken by the performing party in the first

\footnotetext{
64 See Mühl, Hadding, supra note 44, p. 1199; Księżak, supra note 10, p. 46.

65 On this theory see Mühl, Hadding, supra note 44, p. 1199; Księżak, supra note 10, p. 46.

66 Mühl, Hadding, supra note 44, p. 1199.

67 Ibidem.

68 Ibidem.

69 BGHZ 35,103,107; BGHZ 36,395,399; BHGZ 44,1,6.

70 Dannemann, supra note 52, p. 314.

71 See the doctrines mentioned in Mühl, Hadding, supra note 44, p. 1199.

72 Medicus, supra note 45, p. 249.
} 
is high. In other words, whoever acts outside the field of law and good morals does so on his own risk ${ }^{73}$. However, if the parties trust each other and both want to make an unlawful or immoral transaction, the risk is irrelevant. For the simple reason the doctrine is true only to a very limited extent and does not explain the ratio legis of the provision.

Another justification says that courts would be tainted if they were to assist one villain in his claim against the other or that the dignity of the courts prevents them from assisting one villain against the other. This argument is not fully convincing, because the courts often deal with litigations where at least one party is dishonest, immoral, or infringes the law. "What could taint courts, though, is if they were forced to allow an action the success of which offends acknowledged legal or public policy"74.

According to the next point of view where both parties are equally immoral, neither of them deserves protection and can expect a favourable position ${ }^{75}$. In fact, this solution puts the recipient in a better situation. It can lead to ridiculous results, especially in a case of bribery of a civil servant, where the servant's action is punishable by the penal law, but he does not have to give the money back in spite of his being regarded as more reprehensible than the giver ${ }^{76}$.

Heinrich Honsell proposed justification which to a considerable extent relies on the doctrine of Roman lawyers. In his opinion the Roman maxim in pari turpitudine melior est causa possidentis provides the best solution of the problem of performance made for mutually unlawful or immoral purpose. His explanation of this view resembles the motives raised by the Romans, in particular that where both parties are tainted by an evil, there is no justification for changing the existing state of affairs ${ }^{77}$.

In judicial practice $\S 817$ (2) is interpreted restrictively and its exceptional character is often emphasized 78 . This very strict interpretation

\footnotetext{
73 BGHZ 41,341,343; BGH NJW 1997,2381.

74 Dannemann, supra note 52, p. 314.

75 Brox, Walker, supra note 36, p. 471.

76 Ibidem.

77 See Honsell, supra note 1, passim.

78 Mühl, Hadding, supra note 44, p. 1204; Gramm, supra note 55, p. 1201; Schäfer, supra note 37, p. 2619.
} 
and narrow field of application allow the courts to avoid undesirable decisions which may undermine the sense of justice. In some cases the provision indeed can lead to an unacceptable result; therefore, the courts refuse to apply it. Although as a rule the recipient's position is better than the giver's, there are cases where the giver deserves better protection. One of the most important examples is illegal work (Schwarzarbeit), here the worker's claim for remuneration is recognized despite the violation of the statutory prohibition ${ }^{79}$. This flexible approach stems from the assumption that the content and purpose of the statutory prohibition must be taken into account, so therefore not every instance of its violation excludes recovery. Moreover, the German Supreme Court (Bundesgerichsthof) points out that a claim for remuneration can be based on the unjustified enrichment law, even when both parties were aware of the illegal character of the work, because unjustified enrichment claims belong to the equitable law (Billigkeitsrecht) and are subject to the principles of good faith. It will be inconsistent with those principles when the defendant does not have to pay remuneration for the work which he has illegally obtained ${ }^{80}$.

Apart from the objective premises of the application of $\S 817$ (2) the subjective requirements are very important. The requirements are another field of controversy and disputes ${ }^{81}$.

The provision refers to the situation where the direct purpose (Zweck) and not only the motive (Beweggrund) of the performance offends statutory prohibition or good morals. Where the purpose itself is honest, the illegal or immoral motive is irrelevant ${ }^{82}$. The purpose is assessed in the light of circumstances that existed at the time the performance was made 83 .

The issue of whether the parties should be aware of the violation of a statutory prohibition or good morals is very controversial. According to one of the views, the parties should be aware of the consequences

\footnotetext{
79 On the Schwarzarbeit see Mühl, Hadding, supra note 44, p. 1202; Gramm, supra note 55, p. 1201.

80 BGHZ 111,308,312.

81 Lieb, supra note 44 , p. 1403 et seq.

82 Mühl, Hadding, supra note 44, p. 1204; Lieb, supra note 44, p. 1392; Gramm, supra note 55, p. 1201.

83 Mühl, Hadding, supra note 44, p. 1204; Lieb, supra note 44, p. 1392; Gramm, supra note 55, p. 1202.
} 
of the performance or even aware that they are intentionally violating a statutory prohibition or good morals ${ }^{84}$. The opposite view says that there is no such a requirement. It is enough that the parties know the circumstances in which the performance is made. They do not necessary have to be aware of the consequences of those circumstances, in particular that the performance violates law or good morals ${ }^{85}$. In the case of the statutory prohibition this problem is simpler because of the assumption that everybody knows the law and ignorantia iuris nocet. In case of violation of morality it is not so obvious. Moreover, moral standards are not constant, but they change over time ${ }^{86}$. The allegation based on $\S 817$ (2) is taken into account by the courts ex officio, even when the defendant does not raise it ${ }^{87}$.

\section{ENGLISH LAW}

It is interesting to note that unjust enrichment as a independent field of law was finally accepted in English law in 199188, first textbook on restitution was published in $1966^{89}$ and even in 1978 Lord Diplock declared that "[ $\mathrm{t}]$ here is no general doctrine of unjust enrichment recognized in English law. What it does is to provide specific remedies in particular cases of what might be classified as unjust enrichment in a legal system that is based on the civil law"90. However, the previous absence of the "general doctrine of unjust enrichment" does not mean that the idea behind the doctrine is also so young. On the contrary, it has existed in the common law for centuries, especially since as early as in 1760 Lord Mansfield described various circumstances in which a transfer of value needs to be reversed ${ }^{91}$. Since that time English law (and generally common

\footnotetext{
84 See the views presented in Lieb, supra note 44, p. 1404 and in Gramm, supra note 55, pp. 1201 and 1202; Księżak, supra note 10, p. 36.

85 Mühl, Hadding, supra note 44, p. 1204.

86 It is best seen in the people's approach towards prostitution.

87 Brox, Walker, supra note 36, p. 471; Mühl, Hadding, supra note 44, pp. 1203 and 1220; Gramm, supra note 55, p. 1203.

88 See Lipkin Gorman v. Karpmale Ltd (1991) 2 AC 548.

89 Lord Goff of Chieveley, G. Jones, The Law of Restitution, London: Sweet and Maxwell 1966.

90 Orakpo v. Manson Investments Ltd (1978) AC 95,104.

91 Moses v. Macferlan (1760) ER 676 KB.
} 
law) has required the plaintiff to establish a positive reason for recovery by satisfying one of the accepted grounds of restitution, it is not enough that the defendant's retention is without legal ground ${ }^{92}$. This is its main distinctive feature, especially in comparison with the civil law approach. This is the so called "unjust factors approach" still dominant in common law. The most important grounds of restitution (unjust factors) are: mistake of fact or law 93 , practical compulsion, legal compulsion, exploitation, failure of consideration, ultra vires demands of public authorities, necessity and illegality ${ }^{94}$. The last ground - illegality - is particularly important in respect to the recovery of performance for a mutually immoral purpose.

At the beginning of the new millennium, one of the greatest specialists in restitution law Professor Peter Birks proposed a new approach as an alternative to the "unjust factors" - so called "no basis approach". Peters Birks argued that in the so called "swaps cases"95 English law changed direction ${ }^{96}$. In his opinion English law embraced the civilian approach, whereby liability turns on whether there is a valid ground for the receipt of the enrichment. The restitution follows because there is no basis for the payment made, so an enrichment at the expense of another is unjust when it is received without explanatory basis. In this way P. Birks proposed to replace the positive requirement of an unjust factor with the negative requirement of an absence of basis. Today there is a dispute as to which of the two doctrines is better, however the "unjust factors" seems to prevail over "no basis" 97.

\footnotetext{
92 J. Beatson, E. Schrage (eds), Cases, Materials and Texts on Enrichment Unjustified, Oxford-Portland: Hart Publishing 2003, p. 252.

93 In fact, it is disputed whether mistake as to the law constitutes a ground of restitution, see P. Birks, Recovering Value Transferred Under an Illegal Contract, Theoretical Inquiries in Law 2000, vol. 1.1, p. 196 et seq.

94 About each of the grounds see materials and cases in Beatson, Schrage, supra note 92, p. 252 et seq.; N. Neumayer, Unjust Factors or Legal Ground? Absence of Basis the English Law of Unjust Enrichment, European Journal of Legal Studies 2014, vol. 7, no. 2, p. 122 et seq.

95 The key case is Kleinwort Benson v. Lincoln County Council (1992) 2 AC (HL) 349.

96 P. Birks, Unjust Enrichment, Oxford: Oxford University Press 2005, p. 101 et seq.

97 A. Burrows, Absence of Basis: The New Birksian Scheme, [in:] A.S. Burrows; Alan Rodger of Earlsferry, Lord (eds), Mapping the Law. Essays in Memory of Peter Birks, Oxford: Oxford University Press 2006, p. 44 et seq.; J. Edelman, The Meaning of "Unjust" in the English Law of Unjust Enrichment, European Review of Private Law 2006, vol. 14, no. 3, p. 326 et seq.; M. McInnes, The Reason to Reverse: Unjust Factors and Juristic Reasons, Boston University Law Review 2012, vol. 92, no. 3, p. 1049 et seq.; C.D.L. Hunt, Unjust Enrichment Understood
} 
The consequence of a finding of illegality in English law is that the contract is null and void. No action may be brought for compensation for non-performance, nor may an order for specific performance be available ${ }^{98}$. English law adopts an extremely wide view as to what amounts to an illegal contract. It includes contracts to commit crimes, as, for example, a contract to kill or to injure another person, but also contracts of which performance, though not illegal in any criminal sense, will not be enforced for various reasons of public policy. Examples are as follows: marriage brokerage contracts, contracts to commit civil wrongs, contracts to indemnify another against liability for unlawful acts, contracts in restraint of marriage, contracts promoting sexual immorality, contracts of insurance where there is no insurable risk, contracts purporting to oust the jurisdiction of the courts, trading with the enemy, and contracts restricting personal liberty ${ }^{99}$.

The examples show that there is no clear distinction between illegality and immorality in common law ${ }^{100}$. The basic rule is that every illegality is turpitudinous, but certain cases of very serious turpitude are discerned and treated in different ways.

In England at the beginning, a performance made under illegal transaction had to be returned even where both parties were illegal. There was no exception to the rule that money paid for an illegal purpose had to be recovered. The principle in pari delicto melior est condictio defendentis was invoked for the first time in 1760 in Smith v. Bromley101. However even in 1782, in Neville v. Wilkinson, Lord Thurlow observed that "if courts of justice mean to prevent perpetration of crimes, it must be not by allowing a man who has got possession to remain in possession, but by putting the parties back to the state in which they were before" 102 .

as Absence of Basis: a Critical Evaluation with Lessons from Canada, Oxford University Comparative Law Forum 2009, no. 6, available at: http://ouclf.iuscomp.org/ articles/hunt.shtml [last accessed: 24.10.2015]; N. Neumayer, supra note 94, p. 131 et seq.

98 W.J. Swadling, The Role of Illegality in the English Law of Unjust Enrichment, [in:] D. Johnston, R. Zimmermann (eds), Unjustified Enrichment. Unjust Enrichment. Key Issues in Comparative Perspective, Cambridge: Cambridge University Press 2002, p. 289.

99 Ibidem, p. 289 et seq.

100 Cf. Księżak, supra note 10, p. 68 et seq.

101 Ibidem, p. 70.

102 E. Sabbath, Denial of Restitution in Unlawful Transactions - a Study in Comparative Law, part I, International and Comparative Law Quarterly 1959, vol. 8, no. 3, p. 490. 
Soon afterwards the defence of illegality became fully recognized. Illegality per se operated (and still operates today), not as a ground of restitution but rather, as a general bar against the enforcement of illegal transactions ${ }^{103}$ and against restitution of any benefits conferred under them ${ }^{104}$. In 1775 Lord Mansfield explained that:

"The objection, that a contract is immoral or illegal as between plaintiff and defendant, sounds at all times very ill in the mouth of the defendant. It is not for his sake, however, that the objection is ever allowed; but it is founded in general principles of policy, which the defendant has the advantage of, contrary to the real justice, as between him and the plaintiff, by accident, if I may say so. The principle of public policy is this: ex dolo malo non oritur actio. No court will lend its aid to a man who founds his cause of action upon an immoral or an illegal act. If, from the plaintiff's own standing or otherwise, the cause of action appears to arise ex turpi causa, or the transgression of a positive law of this country, there the court says he has no right to be assisted. It is upon that ground the court goes; not for the sake of the defendant, but because they will not lend their aid to such a plaintiff. So if the plaintiff and defendant were to change sides, and the defendant was to bring his action against the plaintiff, the latter would then have the advantage of it; for where both were equally in fault, potior est conditio defendentis" 105 .

Similar reasoning is still applied today. As a justification for the common law approach it is said that: "the courts will not assist a plaintiff who has been guilty of illegal or immoral conduct of which the courts should take notice"106; "the courts will not assist an illegal transaction in any respect"107; "no polluted hand shall touch the pure fountains of justice"108; "no one can be allowed to take advantage of his own dishonesty"109; "he must not expect that a judicial tribunal will

\footnotetext{
103 If the contract is illegal, the courts will allow no action on it, see Birks, supra note 93, p. 155.

${ }^{104}$ Beatson, Schrage, supra note 92, p. 329.

105 In Holman v. Johnson (1775), 1 Cowp. 341,343.

106 Euro-Diam Ltd. v. Bathurst (1988) 2 All ER 23, p. 28.

107 Edgar v. Fowler (1803) 3 East's Rep. 222, p. 225.

108 Collins v. Blantern (1767) 2 Wilson 341, p. 350.

109 Tinker v. Tinker (1970) I All ER 540.
} 
degrade itself by an exertion of its powers, by shifting the loss from the one to the other, or to equalize the benefits or burdens which may have resulted by violation of every principle of morals and laws"110. It is elementary law according to which a court will not enforce a contract or arrangement which is tainted with illegality (ex turpi causa non oritur actio); and that where money or property has been transferred under an illegal agreement, the court will not assist the transferor to recover it from the transferee (in pari delicto potior est conditio defendentis) $)^{111}$. In Singh v. Ali Lord Denning took the view that where two persons conspired to effect a fraudulent or illegal purpose, and property was transferred in pursuance of that purpose, "the transferee, having obtained the property, can assert his title to it against all the world, not because he has any merit of his own, but because there is no one who can assert a better title to it. The court does not confiscate the property because of the illegality - it has no power to do so - so it says, in the words of Lord Eldon: "[1]et the estate lie where it falls" 112 .

Apart from that P. Birks pays attention to other grounds. He points out that the law of unjust enrichment should be consistent with contract law. If the contract is void and neither party can demand counterperformance or damages for non-performance ${ }^{113}$, the result desired by the party should not be achieved by recourse to unjust enrichment claim. As P. Birks writes "[r]ecovery is always denied where to allow it would stultify the law's refusal to enforce the contract. (...) It is undeniable that to allow the plaintiff to recover value transferred under an illegal contract must prima facie reduce the risks of illegal conduct and encourage the plaintiff and others like him to neglect the law's requirements (...). Thus there is in general a danger that, if the law were to allow recovery in this kind of situation, it would make nonsense of its own position in relation to an illegal contract"114. The permission

\footnotetext{
110 Bartle v. Nutt (1840) 9 US 45, 49.

111 G. Kodilinye, A Fresh Approach to the Ex Turpi Causa and "Clean Hands" Maxim, The Denning Law Journal 1992, vol. 1, p. 94.

112 Singh v. Ali (1960) AC 167 at p. 176.

${ }^{113}$ According to the principle recognized in common law ex turpi causa non oritur actio (from a disgraceful cause arises no action).

114 Birks, supra note 93, p. 161.
} 
of recovery in such circumstances can be seen as a means of protection of the party who infringes the law and morality entering into illegal contract. That would encourage the neglect of the requirements of law and morality.

The rule is not considered a strict one, because the courts have created many exceptions which have enabled them to render decisions in the light of the circumstances of each case, rather than in accordance with any rigid rule ${ }^{115}$.

There are four circumstances recognized as permitting recovery in spite of illegality. The first circumstance is repentance and abandonment of the illegality, where restitution of any benefit conferred is available to a party who withdraws from the illegality in question (locus poenitentiae) ${ }^{116}$. It concerns a person who has entered into an illegal contract and then decides to withdraw from it at any time before any of the illegal purpose has been fulfilled ${ }^{117}$. As it was said in Taylor v. Bowers: "[i]f money is paid, or goods delivered for an illegal purpose, the person who has so paid the money or delivered the goods may recover them back before the illegal purpose is carried out" 118 .

However, the change of mind must be genuine and unforced, so it leads to the voluntary abortion of the illegal project. This circumstance is often criticized by scholars. It has been said, for instance, that the true test should not be in the question whether or not the illegal purpose has been executed, but the actual consequences of the restitution of the money. Thus, recovery should be granted only if it prevents the performance of crime ${ }^{119}$. The doctrine of locus poenitentiae was, however, adopted in most cases with but few exceptions ${ }^{120}$.

The second circumstance is where the illegality is aimed at protecting a vulnerable class of persons to which a claimant belongs, e.g. tenants

\footnotetext{
115 Sabbath, supra note 102, p. 490.

116 Taylor v. Bowers (1876) 1 QBD 291.

117 For details see Birks, supra note 93, p. 188 et seq.; E. Sabbath, Denial of Restitution in Unlawful Transactions - a Study in Comparative Law, part II, International and Comparative Law Quarterly 1959, vol. 8, no. 4, p. 690 et seq.

118 Taylor v. Bowers (1876) 1 QBD 291, p. 300, see also Hastelow v. Jackson (1828) 8 B\&C 22.

119 Sabbath, supra note 117, p. 690 et seq.; cf. Swadling, supra note 98, p. 305.

120 Sabbath, supra note 117, p. 690 et seq.
} 
in suits against the landlords121. It is a case of "transactional inequality" which is shorthand for situations in which the law accepts that in relation to a particular kind of transaction people generally (not just people under a particular disadvantage) are unable to defend their own best interests in the normal way, by bargaining ${ }^{122}$.

The third circumstance is where the parties are not equally to blame - non in pari delicto. It is applied when the plaintiff is innocent of the illegality, as where the plaintiff was either: induced into the illegal contract by the defendant's fraud ${ }^{123}$, pressured by the defendant amounting to duress ${ }^{124}$, or ignorant of some fact making the contract illegal125. The plaintiff must prove that his involvement in illegality was excusable in a manner which the law accepts as negativing the application of the maxim in pari delicto potior est conditio defendentis. This means that a plaintiff must show that he was innocent in that he was mistaken, deceived, oppressed, protected, or penitent ${ }^{126}$. There is no mechanical rule determining whether or not a party to an illegal bargain is in pari delicto. The courts consider all the relevant facts in the case and weigh the faults of each party before granting or denying recovery. In the United States the courts take into consideration the fact that the plaintiff was sick, infirm, aged, lacking in education or business ability, or was in need ${ }^{127}$.

The last circumstance permitting recovery is when the restitution is claimed on other grounds, e.g. when the plaintiff can take advantage of his proprietary claim without relying on the illegality ${ }^{128}$. The permissible plea is: "give it back, it's mine", the impermissible plea is "give it back,

\footnotetext{
${ }^{121}$ Kiriri Cotton Company Ltd. v. Dewani (1960) AC 192.

122 Birks, supra note 93, p. 193 et seq.

${ }^{123}$ Hughes v. Liverpool Victoria Legal Friendly Society (1916), 2 KB 482; Shelley v. Paddock (1980) 1 QB 348.

124 Smith v. Cuff (1817) 6 M\&S 160.

125 Oom v. Bruce (1810) 12 East 225.

126 Birks, supra note 93, p. 165; cf. Sabbath, supra note 117, p. 689 et seq.; Swadling, supra note 98, p. 299.

127 Sabbath, supra note 117, p. 690.

128 Taylor v. Chester (1869) LR 4 QB 309; Bowmakers Ltd. v. Barnet Instruments Ltd. (1945) 1 KB 65; Tribe v. Tribe (1996) Ch 107; Tinsley v. Michilligan (1994) 1 AC 340. About personal and proprietary claims as means of recovery see Birks, supra note 93, p. 163. See also Swadling, supra note 98, p. 294 et seq.
} 
it only became yours because of our illegal transaction"129. This fourth ground is recognized because disqualification attributable to illegality operates differently according to the nature of the right on which the plaintiff relies. However, this circumstance is criticized and rejection of this unexplained difference of treatment of personal and proprietary rights is postulated ${ }^{130}$. This difference leads to the exclusion of the in pari delicto rule.

Besides the main grounds, even more possible grounds for restitution in spite of illegality are mentioned in the court's judgments and literature ${ }^{131}$. For instance, a claim for restitution is allowed in order to evade a greater evil, e.g. an illegal immigrant demands payment for his work ${ }^{132}$ - in this case to rule out the claim by the unpaid illegal immigrant would be to increase the possibility of grievous exploitation, approaching slavery.

None of the grounds applies in the case of a very serious turpitudine. Those who are guilty of commercial child abuse or incitement to mass murder will never fit the description of a restricted class of plaintiff entitled to sue, and no forfeitures inflicted on them will seem out of place or disproportionate ${ }^{133}$.

Common law courts have made so many exceptions to the in pari delicto rule that "the certainty suggested by the expression of the maxim is in many respects illusory"134. In fact the court's attitude must be flexible and take into consideration all relevant circumstances of a particular case $^{135}$. This flexible approach is described as follows:

"Where issues of illegality are raised, the courts have to steer a middle course between two unacceptable positions. On the one hand it is unacceptable that any court of law should aid or lend its authority to a party seeking to pursue or enforce an object or agreement which the law prohibits. On the other hand, it is unacceptable that the court

\footnotetext{
129 Beatson, Schrage, supra note 92, p. 330.

130 Birks, supra note 93, p. 166 et seq.

131 See the survey made by Birks, supra note 93, p. 168 et seq.

132 Nizamuddowlah v. Bengal Cabaret Inc. (1977) 399 NYS 2d. 854.

133 Birks, supra note 93, p. 201.

134 Sabbath, supra note 102, p. 491.

135 Cf. Kodilinye, supra note 111, p. 92.
} 
should on the first indication of unlawfulness affecting any aspect of a transaction, draw up its skirts and refuse all assistance to the plaintiff, no matter how serious his loss or how disproportionate his loss to the unlawfulness of his conduct. (...) [T] he courts have tended to adopt a pragmatic approach to these problems, seeking where possible to see that genuine wrongs are righted, so long as the court does not thereby promote or countenance a nefarious object or bargain which it is bound to condemn. Where the plaintiffs action in truth arises directly ex turpi causa, he is likely to fail. Where the plaintiff has suffered a genuine wrong, to which allegedly unlawful conduct is incidental, he is likely to succeed"136.

Apart from that so called "public conscience test" is applied. In this test the court should seek to answer two questions: "1. whether there had been an illegality of which the court should take notice, and 2. whether in all the circumstances it would be an affront to the public conscience if, by affording him the relief sought, the court was seen to be indirectly assisting or encouraging the plaintiff in his criminal act"137. This test is sometimes considered to be very difficult to apply, since the public conscience might well be affected by matters of an emotional or political nature which the court ought not to be required to take into account ${ }^{138}$.

The English approach, as described above, has been severely criticized for its uncertainties, disputes and controversies. For this reason a change in law, even a legislative reform, was postulated. In 2010 the Law Commission (Law Com No. 320) published its final report 139 "The illegality defence"140 in which this defence is described in detail, among others in reference to unjust enrichment, and list of recommendation is made. The illegality defence arises when the defendant in a private law action argues that the claimant should not be entitled to their normal rights

\footnotetext{
136 Saunders v. Edwards (1987) 2 All ER 651, at p. 665 et seq. See also Euro-Diam Ltd. v. Bathurst (1988) 2 All ER 23; Howard v. Shirlstar Container Transport Ltd. (1990) 3 All ER 366.

137 Thackwell v. Barclays Bank (1986) 1 All ER 676, p. 687.

138 Pius v. Hunt (1990) 3 All ER 344.

139 Before this final report three consultation papers were published: The Effect of Illegality on Contracts and Trusts Law (1999), Consultation Paper No. 154; The Illegality Defence in Tort (2001), Consultation Paper No. 160 and The Illegality Defence. A Consultative Report (2009), Consultation Paper No. 189.

140 Law Commission, The Illegality Defence..., supra note 139, HC 412.
} 
or remedies because they have been involved in illegal conduct which is linked to the claim. The courts have attempted to set out rules to govern this area. However, in Commission's opinion the rules are complex and confused.

Finally the Law Commission recommended that the illegality defence does not need legislative reform as it applies to claims for breach of contract, unjust enrichment, tort, or legal property rights. In all these areas any improvements which were needed would be better made through case law developments ${ }^{141}$. Only in the area of trust is legislative reform recommended and the bill is drafted ${ }^{142}$. As the Commission explains:

"Despite the criticisms that we made of the law in our consultative report, we noted that it was rare for the courts to reach what might be regarded as an «unjust» result. For the most part, the courts applied the illegality defence in a fair fashion, to achieve the right policy outcome. We examined the possible policy rationales for the illegality defence. We concluded that in the vast majority of cases the illegality defence only succeeded where one or more of those policies justified its use. We therefore provisionally recommended that since the common law was already reaching the right result, legislative intervention was neither necessary nor helpful143. (...) In each individual case the courts should consider whether the illegality defence can be justified on the basis of the policies that underlie that defence. The law would be clearer, more transparent and easier to understand if judges discussed these policy considerations openly in relation to the facts of the case before them" 144 .

\section{CONCLUSIONS}

This short study, which is limited to only three legal systems, shows how difficult the problem of performance for illegal or immoral purpose

\footnotetext{
141 Ibidem, point 1.11.

142 Ibidem, points 1.14, 1.17 .

143 Ibidem, point 3.8 .

144 Ibidem, point 3.10 , see also point 3.37 .
} 
is. My first conclusion is that there is no perfect solution because each of the discussed solutions has drawbacks and can lead to a highly unsatisfactory result or can even pervert justice. That is why it is impossible to find one universal, clear, and reliable remedy. The verdict in each and every particular case must be left to the judicial branch, which should take into consideration all the relevant circumstance of the case.

Roman law proposed a very simple maxim that should govern this field - in pari delicto potiorem esse possessorem. The outcome of a dispute depended only on one factor - the fact of possession itself was decisive and further grounds became irrelevant or at least they are not mentioned in the sources. It proves the important rule of possessio in ancient Rome. However, this very simple remedy is not convincing, not satisfactory, or even not adequate today. In German law a similar maxim is applied. However the courts seek a more convincing and adequate basis for their verdicts. English law operates with the notion conditio defendentis, which means that the focus rests not so much on possession, but the law favours the defendant, unless there are special grounds to provide otherwise.

As the study in German law and English law proves, the maxim in none of its versions is the true solution to the problem. The doctrine and case law still invoke the maxim, but in fact search for a better and more convenient ground. As a rule the plaintiff is not entitled to recovery, but it is only a rule which has many exceptions and can lead to undesirable results. There are many justifications for this solution: in particular the dignity of the court and the deterrent effect play a very important rule. None of the grounds is undisputable and free from controversy. 